\title{
To Whom It May Concern: International Human Rights Law and Global Public Goods
}

Daniel Augenstein

Tilburg Law School, D.H.Augenstein@uvt.nl

Follow this and additional works at: https://www.repository.law.indiana.edu/ijgls

Part of the Comparative and Foreign Law Commons, Human Rights Law Commons, International Law Commons, and the Law and Economics Commons

\section{Recommended Citation}

Augenstein, Daniel (2016) "To Whom It May Concern: International Human Rights Law and Global Public Goods," Indiana Journal of Global Legal Studies: Vol. 23 : Iss. 1 , Article 10.

Available at: https://www.repository.law.indiana.edu/ijgls/vol23/iss1/10

This Article is brought to you for free and open access by the Law School Journals at Digital Repository @ Maurer Law. It has been accepted for inclusion in Indiana Journal of Global Legal Studies by an authorized editor of Digital Repository@Maurer Law. For more information, please contactrvaughan@indiana.edu.

\section{$\Psi$}

JEROME HALL LAW LIBRARY

INDIANA UNIVERSITY

Maurer School of Law
Bloomington 


\title{
To Whom It May Concern: International Human Rights Law and Global Public Goods
}

\author{
DANIEL AUGENSTEIN*
}

\begin{abstract}
Public goods and human rights are sometimes treated as intimately related, if not interchangeable, strategies to address matters of common global concern. The aim of the present contribution is to disentangle the two notions to shed some critical light on their respective potential to attend to contemporary problems of globalization. I distinguish the standard economic approach to public goods as a supposedly value. neutral technique to coordinate economic activity between states and markets from a political conception of human rights law that empowers individuals to partake in the definition of the public good. On this basis, I contend that framing global public goods and universal human rights in terms of interests and values that "we all" hold in common tends to conceal or evade conflicts about their proper interpretation and implementation. This raises important normative questions with regard to the political and legal accountability of global ordering in both domains. The public goods approach has responded to this problem by extending the scope of political jurisdiction over public goods to encompass all those "affected" by their costs and benefits. This finds its counterpart in attempts in the human rights debate to legally account for the global human rights impacts of public goods through extending human rights jurisdiction beyond state territory. By way of conclusion I contend that both approaches are indicative of a "horizontal" transformation of statehood under conditions of globalization aimed at recovering the public good beyond the international order of states.
\end{abstract}

* Associate Professor, Tilburg Law School and Humboldt Senior Research Fellow, Wissenschaftszentrum Berlin. E-mail: D.H.Augenstein@uvt.nl.

Indiana Journal of Global Legal Studies Vol. 23 \#1 (Winter 2016)

(C) Indiana University Maurer School of Law 


\section{INTRODUCTION}

Public goods and human rights are sometimes treated as intimately related, if not interchangeable, strategies to address contemporary problems of globalization. In a study sponsored by the United Nations Development Program (UNDP) to make public goods fit for development, Inge Kaul and her collaborators treat respect for human rights and international human rights law as a "[g]lobal public good!" because its "benefits extend to all countries, people, and generations." Others have argued that what ties the two notions together is their "universal, indivisible and mutually interdependent [nature], founded on the principle that goods as well as human rights must be accessible to all." 2 Thus, it would appear that what global public goods and universal human rights share is that they are of common concern to the whole of humanity. This common concern is expressed through global interdependencies in the production and consumption of public goods, in the case of the former, and universal membership in the human family of rights-bearing subjects, in the case of the latter. Conversely, much of the appeal of global public goods and universal human rights lies in their purported ability to transcend the compartmentalization of the globe into territorial state entities that are increasingly found wanting in governing the world. Decentering public goods and human rights from the international order of states thus represents an important attempt to redress the imbalance between the transboundary impacts of economic globalization and state-territory-based forms of legal and political rule.

One of my goals in this contribution is to disentangle the notions of public goods and human rights and to shed some critical light on their respective potential to address matters of common global concern. I distinguish the standard economic approach to public goods as a supposedly value-neutral technique to coordinate economic activity between states and markets from a political conception of human rights law that empowers individuals to partake in the definition of the public good. This distinction plays off the economic and political understandings of "public good" as, respectively, the good whose production requires state intervention to prevent market failures and

1. Inge Kaul \& Ronald U. Mendoza, Advancing the Concept of Public Goods, in Providing Global Public Goods: Managing Globalization 78, 95, 98 (Inge Kaul et al. eds., 2003).

2. Birgit Lindsnæs, The Global and the Regional Outlook: How Can Global Public Goods Be Advanced from a Human Rights Perspective?, in TowARDS NEW GLOBAL STRATEgies: Public Goods and Human Rights 71, 73 (Erik André Andersen \& Birgit Lindsnæs eds., 2007). 
the good as a normative standard to evaluate the justice of legal arrangements that make up the state polity. ${ }^{3}$ On this basis, I contend that while economic decisions concerning the production, distribution, and alignment of public goods are an expression of the public good, human rights play a constitutive role in its political definition.

The different ways in which public goods and human rights relate to the public good traditionally vested in the nation-state translate into distinctive challenges to their capacity to address matters of common global concern. On the one hand, the globalization of public goods absent $a$ global public good is marked by their functional differentiation. On the other hand, the constitutive role of human rights in the political definition of the public good remains confined to the territorial state legal order. This leads me to my second goal: to show that positing interests and values that "we all" hold in common is insufficient to account for public goods and human rights at the global level. To be sure, the language of global public goods and universal human rights signals that many challenges bound up with globalization (be it the mitigation of global climate change or the alleviation of world poverty) exceed the traditional state-based distinctions between domestic and foreign politics, and between constitutional and international law. Yet framing public goods and human rights in terms of common interests and values tends to conceal or evade conflicts about their proper interpretation and implementation that persist in the international order of states. This raises important normative questions about the political and legal accountability of global ordering in both domains. The public-goods approach has responded to this problem by extending the scope of political jurisdiction over public goods to encompass all those "affected" by their costs and benefits. This finds its counterpart in attempts in the human rights debate to account legally for the global human rights impact of public goods by extending human rights jurisdiction beyond state territory. Taken together, these approaches suggest a "horizontal" transformation of statehood under conditions of globalization aimed at recovering the public good beyond the international order of states.

3. In a similar way, Malcolm Langford distinguishes a "positivistic" approach to public goods that he associates with Anglo-American welfare economics from a "constructivist" understanding of public goods as a matter of social construction and social contestation. See Malcolm Langford, Keeping Up with the Fashion: Human Rights and Global Public Goods, 16 INT'L J. ON MINORITY \& GROUP RTS. 165, 171-75 (2009). 


\section{Public Goods Without The Public Good?}

Under the standard economic approach, goods are considered public if they are non-rival in consumption and have non-excludable benefits. ${ }^{4}$ Non-rivalry means that one person can consume the good without diminishing its availability to others; non-excludability means that people cannot be excluded from the benefits of the good irrespective of whether they contributed to its production. A commonly used example of a "pure" public good is clean air, because it is not depleted by breathing (non-rivalry in consumption) and cannot be appropriated by a few (nonexcludability of benefits). ${ }^{5}$ The distinguishing feature of public goods (as opposed to private goods) is that, while their provision is considered to be in the common interest, the market creates insufficient incentives to produce them because they cannot be effectively priced and allocated through market transactions. ${ }^{6}$ The non-excludability of benefits leads to an underproduction of public goods since it creates incentives to free ride on the efforts of others. At the same time, their non-rivalry entails that public goods can be consumed at no marginal cost, which makes it inefficient to encourage their production by enhancing their scarcity value.

Against this background, the core concern behind the standard economic approach is to identify those goods whose production requires public (state) intervention to ensure sufficient supply and prevent market failures. The criteria of non-excludability and non-rivalry determine whether a good is "public" or "private" and whether,

4. The development of the economic theory of public goods is commonly associated with Paul Samuelson's discussion of "collective consumption goods." See generally Paul A. Samuelson, The Pure Theory of Public Expenditure, 36 REv. ECON. \& STAT. 387 (1954). This theory found its way into political science with Mancur Olson's work on free-rider problems associated with the production of public goods in large-scale democracies. See generally MANCUR OLSON, THE LOGIC OF COLLECTIVE ACTION: PUBLIC GOODS AND THE THEORY OF GROUPS (1965).

5. Unlike "pure" public goods, "club goods" are non-rival but excludable, while "common pool resources" are non-excludable but rival.

6. The problems bound up with the production of public goods can vary depending on the nature of the good in question. In this vein, Bodansky distinguishes between "aggregate effort" problems where the total supply of the good depends on the aggregate efforts of all actors involved (as in the case of climate change mitigation); "weakest-link" problems where the efforts of the vast majority of actors can be undone by a small group that fails to do its part (for example, hamstringing terrorist financing); and "single-best effort" problems, such as medical discoveries, where the production of the good only depends on the effort of an individual or a small group of actors. See Daniel Bodansky, What's in a Concept? Global Public Goods, International Law, and Legitimacy, 23 EUR. J. INT'L L. 651, 658-66 (2012). 
accordingly, the state or the market should provide it. This entails that the very distinction between "public" and "private" goods is drawn with a view to coordinating economic activity (production and consumption), which renders the public-as-political a residual category, parasitic on the logic of market efficiency. The standard economic approach to public goods thus yields the conclusion

\begin{abstract}
that a good with potentially rival and excludable properties is-or ought to be-private and that its provision ought to be left to the market. This means that the decision about which goods to make private and which public is seen largely as a technical rather than a political matter. The state's role becomes one of providing "market rejects"--non-rival and nonexcludable goods that do not fit the conditions of market transactions. ${ }^{7}$
\end{abstract}

That Inge Kaul and her collaborators alternate between a positive ("is") and a normative ("ought") approach to public goods is indicative of the inconclusiveness of the criteria of non-excludability and non-rivalry in establishing a bright-line distinction between "public" and "private." To return to the above example, the "public" good of clean air has, under modern conditions of large-scale industrial production and pollution, become rival in many parts of the world. By the same token, regulation aimed at curbing pollution (be it in the form of prohibitions or permits) excludes certain actors from the benefits of using clean air in particular ways without, however, turning it into a "private" good. That a good may have some rival and excludable properties does not appear decisive for its categorization as "public" or "private." Moreover, whether a good has rival and excludable properties is often not a natural state of affairs but the result of human intervention. As Kaul and Mendoza say, "[b]efore goods appear in the market or in the portfolio of state agents, policy choices have been made or norms established to make the goods private in the sense of being exclusive or public in the sense of being non-exclusive." 8

A related problem arises with regard to the distinction between public "goods" and public "bads." Imagine that the air pollution in our example is a by-product of oil extraction (so-called gas flaring) in a developing country that has detrimental health impacts on the local oil-

7. Inge Kaul, Pedro Conceição, Katell Le Goulven \& Ronald U. Mendoza, How to Improve the Provision of Global Public Goods, in Providing Global Public Goods: MANAGING GLOBALIZATION, supra note 1 at 21, 23.

8. Kaul \& Mendoza, supra note 1 , at 86 . 
producing community. It may appear commonsensical that the state should intervene to protect the public good of clean air by curbing the pollution-intensive production. The problem with this line of argument, however, is that the criteria of non-rivalry and non-excludability do not lend themselves to such normative evaluation, with the consequence that the standard economic approach must presuppose that the production of any given good or bad is desirable or undesirable. Yet people (in casu, the oil industry and the oil-producing community, members of the community employed by the oil industry, those whose crops are damaged by the carbon fallouts, etc.) will disagree about what should count as a public "good" and how it should be produced given limited resources. Once again, the basic point is that the production of public goods involves political choices that cannot be gauged by a technical exercise in economic optimization.

A related political blind spot of the standard economic approach is that its preoccupation with the market-efficient production of public goods marginalizes the problem of their equitable distribution. The oil production in our local community may constitute the developing country's main source of foreign investment and tax revenue, a significant part of which is used to maintain the public health system. Instead of a simple conflict between a public "good" (clean air) and a public "bad" (air pollution), this scenario presents a more complex challenge involving competing public goods (economic development and public health), the provision of which may appear to be of overriding importance especially to those living in other parts of the country. At the same time, financing the public health system through oil revenues imposes disproportionate costs on people in the oil-producing community, who may in turn request a greater share in the benefits to offset the pollution-induced externalities.

At issue here are political conflicts between actors with different interests over the distribution of the costs and benefits involved in the production and consumption of public goods. Economists usually rely on the market to allocate goods between citizens via a cost-benefit analysis geared toward wealth maximization. Whatever the merits of such an approach with regard to "private" goods, it cannot work in relation to "public" goods that require government intervention precisely in order to avert market failures. This poses the problem of how to reveal and aggregate individuals' preferences concerning the equitable distribution of public goods-a problem that the standard economic approach can only address either by presupposing that public goods were in fact non- 
rival and non-excludable and therefore distribution-neutral, ${ }^{9}$ or by falling back on the political process vested in state-type democracies. ${ }^{10}$

In sum, the standard economic approach proves unsatisfactory because, although it needs to concede that in reality most public goods (and, in any case, all those pertinent to an economic analysis) are "impure" (i.e., have excludable or rival properties), it denies the constitutive role of politics in decisions concerning their production, distribution, and alignment. Its ostensibly technical and value-neutral definition of public goods on grounds of market efficiency conceals that the distinction between (what ought to be) public and (what ought to be) private is itself a public and political decision. Relatedly, allocating the costs and benefits of public goods on the basis of individual-preference aggregation presupposes, rather than justifies, a distributive scheme grounded in the shared commitments of the members of a political collective. As Loader and Walker argue, by relying on purely instrumental reasons to overcome the "short-term self-interest and information] deficiency of the market model," the standard economic approach to public goods "assume[s] the very collective commitment to put things in common in this rather than any other group that it [needs] to demonstrate."11 A political conception of public goods, by contrast, must be "predicated upon a set of actual or projected ends which vindicate the very value of conceiving and pursuing ends as common ends ...."12 The way in which a political collective comes to conceive and pursue ends as common ends, finally, elucidates the political role of the public good in framing decisions and resolving conflicts about the production, distribution, and alignment of public goods. If the latter concerns the allocation of goods in matters of public interest, the former concerns the way in which a political collective relates to its own publicness. The public good as the "common weal" or the "common good" is a representation of the general interest that all members of a political collective hold in common. ${ }^{13}$ Accordingly, economic decisions concerning particular public goods are but an expression of the public good as a political relationship aimed at establishing, institutionalizing, and

9. See Meghnad Desai, Public Goods: A Historical Perspective, in Providing GLobal PuBlic Goods: Managing Globalization, supra note 1 at 63, 71-72.

10. See Gregory Shaffer, International Law and Global Public Goods in a Legal Pluralist World, 23 EUR. J. INT'L L. 669, 683 (2012).

11. IAN LOADER \& NEIL WALKER, CIVILIZING SECURITY 162-63 (2007).

12. Id. at 163 .

13. For a historical account of the evolution of the public good as the common good from the Roman notion of "res publica" to a modern republican understanding that emerged in the context of the Great Revolutions, see Peter Wivel, The State and the Citizen: Natural Law as a Public Good, in Towards New Global STRATEgies: Public GOODS AND HUMAN RIGHTS 3 (Erik André Andersen \& Birgit Lindsnæs eds., 2007). 
accounting for the general interest of the polity. Alternatively, conflicts about public goods are resolved in the light of the public good through which individuals come to identify themselves as members of a polity endowed with a common purpose.

\section{AcCounting For Global Public Goods}

The reason I set out to discuss the relationship between public goods and the public good in the context of the nation-state is that it provides a fruitful starting point for examining the problem of global public goods. International law in its classical form has compartmentalized this relationship within and among territorial state entities. On the one hand, the public good is confined to the national political community bounded by the territorial state legal order. This reflects the central role of the national democratic process in organizing the domestic economy and resolving conflicts about public goods. On the other hand, the lack of a global political community that could render decisions about public goods legitimate in the light of $a$ global public good is compensated by imposing a consent requirement on states in international law. The consensual structure of the international legal order is meant to ensure that states represent the collective political will of their citizens when resolving conflicts about public goods in their international dealings with one another. This state-centered approach has increasingly come under attack for its incapacity to address the transboundary challenges involved in the production, distribution, and alignment of public goods under conditions of globalization. The requirement of state consent is seen as an impediment to the effective solution of global collective action problems, with commentators urging reform to enhance international law's problem-solving capacity in matters of common global concern. ${ }^{14}$

At the same time, the confinement of the public good to the territorially-bounded national political community fails to explain why states should take the political interests of outsiders into account. While the economic costs and benefits of state-based decisions concerning public goods are increasingly felt globally, political accountability for such decisions stops at national borders. ${ }^{15}$ Two prongs of the global approach to public goods may be distinguished along these lines. The first prong attempts to transcend the international order of states from "above" by foregrounding public interests of common global concern. The second prong tries to recover political accountability from "below" by

14. For a critical appraisal, see Nico Krisch, The Decay of Consent: International Law in an Age of Global Public Goods, 108 AM. J. INT'L L. 1, 3-6 (2014).

15. See, e.g., David Held, Democratic Accountability and Political Effectiveness from a Cosmopolitan Perspective, 39 Gov'T \& OPPOSITION 364 (2004). 
extending the scope of stakeholders in public goods to encompass all those affected by their costs and benefits. Both prongs, I argue, suffer from shortcomings similar to those of the standard economic approach in that they presuppose, rather than justify, the political terms and conditions under which public goods are produced, distributed, and aligned at the global level.

As noted at the outset, one defining feature of global public goods is that they are said to confer global benefits that "extend to all countries, people, and generations." 16 Indeed, much of the appeal of global public goods lies in their purported ability to reach beyond the international order of states in addressing matters of common global concern. However, positing interests and values that "we all" hold in common at a sufficiently abstract level to command general consent tends to conceal or evade political conflicts about their proper interpretation and implementation. In his contribution to this collection, Neil Walker aptly depicts this problem in terms of a discrepancy between the global ambitions of political morality and the localization of political authority. ${ }^{17}$ The global-public-goods approach may be seen as sidestepping the problem of political authority through the apparent self-evidence of its objectives at the level of political morality. Yet any effective solution at the level of global political morality is likely to be undermined by decentralized structures of political authority.

Consider again the example of clean air. It is not difficult to see how oil production in a developing country confers benefits and produces costs that transcend state borders. Oil production not only generates significant financial revenues for those (Western) countries whose "multi-national" corporations are in charge of the local production process, but also caters to the energy needs of their domestic economies. Moreover, the gas flared in the course of the oil extraction constitutes a major source of carbon-dioxide emissions that accelerate global warming. Viewed from a global perspective, the most cost-effective way to curb carbon emissions for the benefit of all concerned may be to reinsert the gas into the earth's crust or to use it for local energy production-both involving significant costs for a developing state. In response, the state may either prioritize national economic development over global environmental protection, or try to reclaim the costs from the industrialized world, whether in view of their historical record of carbon emissions or in mitigation of future climate change. In the latter vein, some developing countries have proposed to forego further exploitation of their natural resources in exchange for financial

16. Kaul \& Mendoza, supra note 1 , at 95.

17. See Neil Walker, Human Rights and Global Public Goods: The Sound of One Hand Clapping?, 23 IND. J. GLOBAL LEGAL STUD. 249, 249 (2016). 
compensation from other states (a practice sometimes pejoratively referred to as "environmental blackmailing"). ${ }^{18}$

One reason why such initiatives have been remarkably unsuccessful harks back to the problem that the public "good" of clean air and the public "bad" of air pollution cannot be effectively regulated through market transactions but instead require state intervention. Another reason is that states disagree about the allocation of public responsibilities for preventing global market failures that are bound up with the underproduction and overconsumption of clean air. Such political conflicts cannot be resolved by mere appeal to the global public benefits of reducing air pollution because, as I have argued, what is at stake is a whole bundle of interconnected public "goods" and "bads" whose benefits and costs are distributed unevenly across the international order of states. In this vein, foregrounding interests and values of global common concern fails to account for the fact that states' failure to resolve collective-action problems bound up with the production, distribution, and alignment of global public goods is also an expression of conflicting political loyalties they owe to their own citizens.

The second prong of the global approach to public goods attempts to address this problem by way of enhancing political accountability for their transboundary impacts. Here, the emphasis is less on commonality than on the disjuncture that arises from what David Held has termed a "breakdown" of the symmetry and congruence between "decisionmakers" and "decision-takers" under conditions of globalization:

Traditionally, the tension between the sphere of decision-makers and the sphere of decision-takers has been resolved by the idea of political community - the bounded, territorially delimited community in which decision-makers and decision-takers create processes

18. For example, in June 2007, Ecuadorian President Rafael Correa offered to forego oil exploitation in the Amazonian Yasuni Park for the global environmental benefit in exchange for financial contributions from other states, to be paid into a fund jointly administered by Ecuador and UNDP: "Ecuador doesn't ask for charity, but does ask that the international community share in the sacrifice and compensates us with at least half of what our country would receive, in recognition of the environmental benefits that would be generated by keeping this oil underground." Rhett Butler, Ecuador: Pay Us Not to Develop Amazon Oil Reserves, MONGABAY (Apr. 27, 2007), http://news.mongabay.com/ 2007/04/ecuador-pay-us-not-to-develop-amazon-oil-reserves/. In August 2013, the initiative was abandoned due to insufficient contributions from the international state community. See Jonathan Watts, Ecuador Approves Yasuni National Park Oil Drilling in Amazon Rainforest, THE GUARDIAN (Aug. 16, 2013), http://www.theguardian.com/world/2013/ aug/16/ecuador-approves-yasuni-amazon-oil-drilling. 
and institutions to resolve the problem of accountability. . . Globalization, global governance and global challenges raise issues concerning the proper scope of democracy and of a democracy's jurisdiction, given that the relation between decision-makers and decisiontakers is not necessarily symmetrical or congruent with respect to territory..$^{19}$

To redress the ensuing political accountability gap for global public goods, Kaul and Mendoza have proposed a principle of "equivalence of publicness" (derived from the notion of fiscal equivalence) that requires "matching the circle of stakeholders in a particular public good with the circle of participants in negotiations on its provision ...."20 This is to be achieved by expanding decision making "across fiscal or political jurisdictions to encompass all the stakeholders for the good in question." ${ }^{21}$ Kaul and Mendoza's approach proceeds from circumscribing the "scale" of the public good in question (i.e., whether it confers local, national, regional, or global benefits) to identifying those affected by its provision, "independent of the subjective evaluation which individuals attach to the objective benefits derived from the good."22 Though it extends political jurisdiction over public goods across nationalterritorial borders, this approach still falls short of recovering the public good at the global level.

Absent a global conception of political authority that could anchor public goods in the general interest of the cosmopolitan polity, the identification of "all affected" will center on the political stakes that individuals have in particular global public goods (promoting economic development, ensuring environmental sustainability, etc.). This entails that political participation in decisions about global public goods is not intended to account for the general interest of the polity but is rather organized around functionally delimited goals shared among those regulated by a particular process. ${ }^{23}$ Accordingly, the asymmetry and incongruence between decision-makers and decision-takers that stems from the confinement of the public good to the territorial state are resolved by way of a global functional differentiation of public goods. Yet

19. Held, supra note 15 , at $371-72$.

20. Kaul \& Mendoza, supra note 1 , at 91 .

21. $I d$.

22. Id. (quoting Albert Breton, A Theory of Government Grants, 31 CAN. J. ECON. \& PoL. SCI. 175, 176 (1965)) (internal quotation marks omitted).

23. On the democratic shortcomings of the functional approach to global ordering see Gráinne de Búrca, Developing Democracy Beyond the State, 46 Colum. J. TransNaT'L L., $221,242-43,254$ (2008). 
such functional differentiation creates new global asymmetry and incongruence between those actors with conflicting political stakes in different public goods that will often act at cross-purposes. ${ }^{24}$ Moreover, Kaul and Mendoza's proposal to specify affectedness on the basis of an objectified account of "benefits" raises similar concerns about depoliticization as does the standard economic approach. The determination of "all affected" on socio-empirical grounds conceals the fact that identifying the relevant stakeholders in any particular global public good is itself a political question. As Nancy Fraser points out, demarcating the kinds and degrees of affectedness that are deemed sufficient to confer political standing on the individual "requires complex political judgments .. . weighting the relative merits of alternative interpretations of the all-affected principle, which generate alternative accounts of the "who." 25 Seen in this light, the extension of political jurisdiction across national-territorial borders insulates normative judgments about "affectedness" from political contestation by identifying in advance of the political process those with a relevant stake in decisions about global public goods. Finally, these difficulties with framing political accountability in the transnational realm elucidate that the political challenge faced by the global-public-goods approach is not simply one of "scale" (from local to global) but also one of "kind" that concerns the transformation of a purely instrumental conception of public goods into a normative one absent $a$ global public good that "we all" hold in common. ${ }^{26}$

\section{HUMAN RightS AND the PUBLIC GoOD}

) common across a particular community. I am referring to goods values of common global concern does not suffice politically and legally to account for human rights at the global level-regardless of whether one assimilates human rights to global public goods or places them at the heart of a "global citizenship" that "underwrites the autonomy of each and every human being, and recognizes their capacity for selfgovernance at all levels of human affairs." 27 True, the universality of human rights is sometimes treated as a truism. Human rights are

24. A problem very visible in Kaul and Mendoza's scheme of global public goods is that it lists "[r]espect for human rights" next to "[r]espect for national sovereignty" and "[m]ultilateral trade agreements." See Kaul \& Mendoza, supra note 1, at 98.

25. NANCY FRASER, Two Dogmas of Egalitarianism, in SCALES of JUSTICE: Reimagining Political Space in A Globalizing World, 30, 40 (2010).

26. I borrow this distinction between "scale" and "kind" from LOADER \& WALKER, supra note 11 , at 239-45.

27. Held, supra note 15 , at 387 . 
universal because they belong to all human beings by virtue of their being human; or, put the other way around, unless they are universal rights they cannot be human rights:

\begin{abstract}
Human rights are equal rights: one either is or is not a human being, and therefore has the same human rights as everyone else (or none at all). They are also inalienable rights: one cannot stop being human, no matter how badly one behaves nor how barbarously one is treated. And they are universal rights, in the sense that today we consider all members of the species Homo sapiens "human beings," and thus holders of human rights. ${ }^{28}$
\end{abstract}

In spite of their proclaimed universal normativity, human rights are a scarce resource with benefits distributed very unevenly across the globe. Geography plays a decisive role in the global birth lottery, and most "Northerners" happen to live a freer and more equal life than people in the "Global South." Moreover, the criteria for membership in the human family are far from settled, with prospective candidates having ranged from slaves, black people, women, Jews, and homosexuals to corporations that claim their "human" rights to privacy, property, and so on, against the rest of "us." ${ }^{29}$ This inclusion/exclusion dilemma is rooted in the well-known difficulty of "mapping" humanity's universality-by-abstraction onto concrete rights-bearing subjects possessing a particular nationality, gender, age, race, class, and so on.

Finally, people tend to disagree about their concrete due in human rights. Under conditions of political pluralism, any account of rights will "face disagreements about the interests it identifies as rights, and the terms in which it identifies them. Those disagreements will in turn be vehicles for controversies about the proper balance to be struck between some individual interest and some countervailing social consideration." 30 It is not only these rival and conflictive properties of human rights that frustrate any easy attempt to assimilate them to (the standard economic approach to) public goods. An assessment from the

28. Jack Donnelly, Universal Human Rights In Theory and Practice 10 (2d ed. 2003).

29. The European Court of Human Rights, for example, has considered a company "an independent living organism ... whose rights also receive autonomous protection under the European Convention on Human Rights." See Comingersoll S.A. v Portugal, 2000-IV Eur. Ct. H. R. 355 (2000) (Rozakis, J., concurring).

30. Jeremy Waldron, A Right-Based Critique of Constitutional Rights, 13 OxFoRD J. LEGAL STUD. 18, 30 (1993). 
vantage point of their purported non-rivalry and non-excludability also misses the political thrust of claiming human rights as correlative to public duties to respect, protect, and fulfill them-duties that are not subservient to imperatives of economic efficiency. ${ }^{31}$ In the case of an oilrich developing state, while ownership of the land from which the oil is extracted may be considered a "private" good (because land is treated as a rival commodity of exclusionary use to its owner), the question of who (if anyone) is entitled to lay claim to this land as a matter of (private property) right is a public and political question. ${ }^{32}$

The latter distinction between land ownership as a private good and the public allocation of rights to private property sheds light on the internal relationship between human rights protection and democratic self-legislation. Far from being "pre-political" individual entitlements, rights-based claims to private property require an authoritative determination by and for a political community as a whole. Human rights become determinate (in the face of abstraction) and authoritative (in the face of conflict) through their emplacement in political relationships individuated within the state legal order. Human rights are those rights that human beings must accord to each other as members of a polity to legitimately regulate their common affairs under positive law. By empowering those subjected to the state's legal commands to view themselves as their authors, human rights enable individuals to consider state power not merely in terms of factual constraints on their freedom but also as the legitimate expression of collective political will-formation. ${ }^{33}$ As Habermas puts it, "[p]opular sovereignty and human rights provide the two normative perspectives from which an enacted, changeable law is supposed to be legitimated as a means to secure both the private and civic [public] autonomy of the individual." ${ }^{4}$ On the one hand, in the traditional liberal view, human rights erect legitimate barriers to the encroachment of public authorities on the private autonomy of individual legal subjects. On the

31. In this vein, Lindsnæs considers human rights "complementary" to the standard economic approach to public goods because they counteract the latter's "strategic" rationality. See Lindsnæs, supra note 2 , at 74.

32. This distinction is in principle commensurable with considering the right to private property a global public good because it averts the "tragedy of the commons." Yet it should also be noted that the latter view is premised on certain empirical assumptions about the beneficial relationship between the institutionalization of private property regimes and the exploitation of natural resources for which at least the members of a local community suffering from oil-induced environmental degradation will have little patience.

33. See JÜrgen HaBERMAS, Remarks on Legitimation Through Human Rights, in THE Postnational Constellation 113, 114-15 (Max Pensky ed. \& trans., MIT Press 2001) (1998).

34. Id. at 116 . 
other hand, the protective role of human rights in relation to individual freedom cannot be imposed on popular sovereignty in the form of external constraints. Those benefiting from human rights as private individuals must also be able to understand themselves as their authors in the exercise of their public autonomy through democratic selflegislation:

For, in the final analysis, private legal subjects cannot enjoy even equal individual liberties if they themselves do not jointly exercise their civic [public] autonomy in order to specify clearly which interests and standards are justified, and to agree on the relevant respects that determine when like cases should be treated alike and different cases differently. ${ }^{35}$

At the same time, the substantive content of legal human rights cannot be derived from a predetermined ethical self-understanding of national community. Rather, a political collective that commits to protecting human rights empowers individuals to invoke humanity against the polity. Hence, human rights neither entail legal entitlements that human beings possess in advance of democratic selflegislation, nor are they simply the product of collective will-formation among citizens. Rather, the tension between human rights' universal normativity and their institutionalization in particular legal orders is resolved, in an ever-provisional way, through a reflexive political process in which members of the polity recognize each other both as legal subjects and as individual human beings. ${ }^{36}$

Finally, the internal relationship between human rights protection and democratic self-legislation explains the constitutive role of human rights in relation to the public good vested in the nation-state. By according legal protection to human rights, a political collective empowers individuals to stake a political claim in the definition of the public good that establishes, institutionalizes, and accounts for the general interest of the polity. Take the example of the human right to a "general satisfactory environment" that is invoked by members of an oilproducing community against the state and, indirectly, the oil industry

35. JÜRGEN HABERMAS, On the Internal Relation Between the Rule of Law and Democracy, in The INCLUSION OF THE OTHER 253, 262 (Ciaran Cronin \& Pablo De Greiff eds. 1999).

36. Habermas conceives of this tension in terms of the "Janus-faced" nature of human rights, looking both to the open-ended and transformative discourse of universal morality and to their ethical-political institutionalization in particular legal orders. See HABERMAS, supra note 33 , at 118 . 
itself. ${ }^{37}$ An individual's claim that her rights were violated by oilinduced environmental damages is judged in relation to the general interest of a political community, as reflected in its embedded understanding of, say, "the rights of others" and "the common interest." 38 If such a claim is successful, it transforms the very boundaries of the polity and translates into a new self-understanding of what the political community understands the human right to a satisfactory environment to be. That the concrete content of the right is determined in relation to the polity's "common interest" illustrates how the rights-based protection of particular individuals and groups is at the same time of common concern to the political collective as a whole. ${ }^{39}$ For the same reason, human rights cannot be conceived as a functionally differentiated policy domain geared towards the realization of particular interests. The scope of protection of human rights is not contingent on the nature of the interfering policy measure but determined in relation to the general interest of the polity. It is immaterial to the assessment of the ambit of the human right to a generally satisfactory environment whether this right is interfered with in the state's pursuit of national energy production, economic development, or other ends. Inasmuch as human rights are of concern to all sectors of government activity, they mandate legal protection that cuts across functional differentiations. ${ }^{40}$

37. Article 24 of the African Charter on Human and Peoples' Rights protects the right to a general satisfactory environment. African (Banjul) Charter on Human and Peoples' Rights, art. 24, June 27, 1981, O.A.U. Doc. CAB/LEG/67/3 rev. 5, 21 I.L.M. 58 (1982) [hereinafter African Charter], available at http:/www.achpr.org/files/instruments/achpr/ banjul_charter.pdf.

For an illustration of the multi-faceted human rights challenges raised by this example, see the famous "Ogoniland decision" of the African Commission on Human and Peoples Rights, Social and Economic Rights Action Center and the Center for Economic and Social Rights v. Nigeria, Communication 155/96 African Commission on Human and Peoples' Rights [Afr. Comm'n H.P.R.], IT 50-52 (Oct. 27, 2001), available at http://www.achpr.org/files/sessions/30th comunications/155.96/achpr30_155_96_eng.pdf.

38. See, e.g., African Charter, supra note 36, art. 27(2). Other regional and international human rights conventions contain similarly worded limitation clauses.

39. For a related argument from the domain of ethics that shows how human rights are rendered determinate by virtue of the "formal and material constraints" imposed upon them, see JAMES GRIFFIN, ON HUMAN RIGHTS 174 (2008).

40. Perhaps unsurprisingly, this "cross-sectoral balancing" role of human rights has received particular attention in debates concerning human rights protection in the functionally differentiated European Union polity. See, e.g., Neil Walker, Human Rights in a Postnational Order: Reconciling Political and Constitutional Pluralism, in SCEPTICAL Essays on Human Rights 119, 136 (Tom Campbell, K. D. Ewing \& Adam Tomkins eds., 2001) (discussing the idea that human rights span different bodies and establishments); Philip Alston \& J. H. H. Weiler, An 'Ever Closer Union' in Need of a Human Rights Policy: The European Union and Human Rights, in THE EU AND HUMAN RIGHTS 3, 23 (Philip Alston ed., 1999). 
In sum, the constitutive role of human rights in relation to the public good consists in their contribution to the legitimation of state power by representing the general interest of the polity that is not reducible to the aggregated economic self-interest of "isolated" liberal individuals or the provision of functionally differentiated public goods.

\section{DECENTERING HUMAN RIGHTS FROM THE INTERNATIONAL ORDER OF STATES}

If the globalization of public goods is marked by their functional differentiation, international law has traditionally confined the constitutive political role of human rights in relation to the public good to the territorial state legal order. Human rights' universal aspirations constantly run up against the territorial limitations inherent in the state-centered architecture of international law. To be sure, some argue that human rights treaties have a distinctive status in the body of general public international law, be it because they embody universal values of the international community of states and operate as an international ordre publique, or because the fulfillment of a state's international human rights obligations is not conditional upon reciprocity by other states. ${ }^{41}$ This notwithstanding, international law has traditionally not generated individual entitlements to human rights protection by everyone and everywhere, but has instead confined them to a territorially-circumscribed relationship between public authorities and private individuals. As a default rule, each state has a singular legal obligation and prerogative (to the exclusion of other states) to respect, protect, and fulfill the human rights of individuals located in its own territory in relation to acts of its own public authorities. This territorial compartmentalization of human rights in the international order of states, in turn, bears out the political division of labor between constitutional and international law. ${ }^{42}$ As I suggested in Part III, human rights in their constitutional form contribute to the transformation of state power into legitimate forms of legal authority by

41. See, e.g., Matthew Craven, Legal Differentiation and the Concept of the Human Rights Treaty in International Law, 11 EUR. J. INT'L L. 489, 491, 511 (2000) (discussing the different views of human rights treaties, including the beliefs that the treaties might embody international community values or function as an international ordre publique); Bruno Simma, International Human Rights and General International Law: $A$ Comparative Analysis, in 4 COLLECTED COURSES OF THE ACADEMY OF EUROPEAN LAW, no. $2,153,195$ (1995) (noting that typical human rights treaties lack reciprocity between parties).

42. On the distinction between the constitutional and international dimensions of human rights law, see generally Gerald L. Neuman, Human Rights and Constitutional Rights: Harmony and Dissonance, 55 STAN. L. REV. 1863 (2003). 
empowering individuals to partake in the political definition of the public good individuated in the territorial state legal order. At the international level, by contrast, human rights take the form of political agreements between states that oblige each state to respect, protect, and fulfill the rights of individuals within the territorial confines of its own legal order. As a consequence, the impact on human rights of state decisions concerning the production, distribution, and alignment of global public goods on individuals in other states is not traditionally mitigated by corresponding extraterritorial human rights obligations.

Kaul and Mendoza's proposal to extend political jurisdiction over global public goods to encompass all those "affected" by their costs and benefits finds a correlation in attempts in the human rights debate to ensure legal accountability for extraterritorial human rights violations by extending human rights jurisdiction beyond state territory. In general public international law, jurisdiction fulfills "the function of regulating and delimiting the respective competences of States" to lawfully rule over "conduct in matters not exclusively of domestic concern." 43 Jurisdiction circumscribes the conditions under which a state can prescribe and enforce its laws on the territory of another state, in accordance with an internationally recognized basis of jurisdiction and subject to a reasonableness test. ${ }^{44}$ International law thus delimits a state's legal authority over individuals outside its borders by virtue of the authority that other states wield over their territory and people therein. As a consequence, although international law does not explicitly tie human rights jurisdiction to state territory, ${ }^{45}$ their compartmentalization in the international order of states appears to warrant a "primarily territorial" interpretation that renders extraterritorial human rights protection "exceptional" and in need of

43. See F. A. Mann, The Doctrine of Jurisdiction in International Law, 111 RECUEIL DES COURS 1, 9, 15 (1964).

44. See James Crawford, Brownlie's Principles of Public international law 456-86 (8th ed. 2012).

45. Article 1 of the European Convention for the Protection of Human Rights and Fundamental Freedoms simply provides that states shall "secure" human rights "to everyone within their jurisdiction." European Convention for the Protection of Human Rights and Fundamental Freedoms art. 1, Nov. 4, 1950, 213 U.N.T.S. 221. Article 2(1) of the International Covenant on Civil and Political Rights tasks each state party to respect and ensure human rights "to all individuals within its territory and subject to its jurisdiction." International Covenant on Civil and Political Rights art. 2(1), opened for signature Dec. 16, 1966, S. Exec. Doc. E, 95.2 (1978), 999 U.N.T.S. 171, (entered into force Mar. 23, 1976). Other international human rights treaties, including the International Covenant on Economic, Social, and Cultural Rights do not contain a jurisdiction clause at all. International Covenant on Economic, Social and Cultural Rights, opened for signature Dec. 16, 1966, S. Exec. Doc. D, 95-2 (entered into force Jan. 3, 1976), 993 U.N.T.S. 3. 
special justification. ${ }^{46}$ However, the question of whether states are obliged to protect the human rights of individuals outside their borders is not reducible to the question of whether they are entitled to do so pursuant to an internationally recognized basis of jurisdiction. Otherwise, a state could circumvent its obligations under international human rights treaties by exceeding its competences under general public international law. 47 The conditions under which an individual comes under the human rights jurisdiction of a state are thus different from those pertaining to the legality of state action under the general international law of jurisdiction. Whereas the latter regulates the state's legal authority over conduct not exclusively of domestic concern, the former regulates the state's obligations when exercising de facto power and control over an area or individual outside its borders.

In this vein, the United Nations Human Rights Committee concludes that "a State party must respect and ensure the rights laid down in the [International Covenant on Civil and Political Rights] to anyone within the power or effective control of that State party even if not situated within the territory of the State Party. . . [and] regardless of the circumstances in which such power or effective control was obtained . . . "48 Similarly, the European Court of Human Rights has held that the decisive factor for establishing human rights jurisdiction is the state's "exercise of physical power and control," whether lawful or unlawful, over the individual in question. ${ }^{49}$ The allocation of human rights obligations to states is thus not predicated on citizenship or territory but on state power and control over the individual rightsholder. Per the Inter-American Commission on Human Rights, "the inquiry turns not on the presumed victim's nationality or presence within a particular geographic area, but on whether, under the specific circumstances, the State observed the rights of a person subject to its authority and control."50 Similar views have been expressed by other

46. See Bankovi v. Belgium, App. No. 52207/99, 2001-XII Eur. Ct. H.R. 333 ๆๆ 59, 61. While the bulk of Bankovi has meanwhile been overruled, the Court continues to hold fast to the view that extraterritorial human rights protection is exceptional and in need of special justification in light of the sovereign territorial rights of other states. See AI-Skeini v. United Kingdom, App. No. 55721/07, 53 Eur. Ct. H.R. 589 (2011).

47. On this distinction, see generally Daniel Augenstein \& David Kinley, When Human Rights 'Responsibilities' Become 'Duties': The Extra-Territorial Obligations of States that Bind Corporations, in HUMAN RIGHTS OBLIGATIONS OF BUSINESS: BEYOND THE CORPORATE RESPONSIBILITY TO RESPECT? 271 (Surya Deva \& David Bilchitz eds., 2013).

48. U.N. Human Rights Comm., Mar. 29, 2004, General Comment No. 31 [80]: The Nature of the General Legal Obligation Imposed on States Parties to the Covenant, \10, U.N. Doc. CCPR/C/21/Rev.1/Add. 13 (May 26, 2004).

49. Al-Skeini, App. No. 55721/07, 53 Eur. Ct. H.R ๆ 136.

50. Coard v. United States, Case 10.951, Inter-Am. Comm'n H.R., Report No. 109/99, OEA/Ser.L/V/II.106, doc. 3 rev. 137 (1999). 
United Nations treaty bodies, including the committee tasked with the interpretation of the International Covenant on Social, Economic and Cultural Rights, ${ }^{51}$ and the International Court of Justice. ${ }^{52}$ Importantly, the extraterritorial application of human rights treaties is not confined to situations in which state agents operate on foreign soil but also captures conduct in the state's territory that infringes on the rights of individuals outside its borders. Both the European Court of Human Rights and the Inter-American Commission on Human Rights have recognized that "acts and omissions" of state agents that merely "produce effects" outside the state's territory can bring an individual under that state's human rights jurisdiction. ${ }^{53}$ For some United Nations treaty bodies, this implies that states have extraterritorial obligations to "prevent[] their own citizens and national entities" from violating human rights in other countries. ${ }^{54}$ Similarly, the Maastricht Principles define extraterritorial human rights obligations as "relating to the acts and omissions of a State, within or beyond its territory, that have effects on the enjoyment of human rights outside [its borders]." 55

There is a lively doctrinal discussion about the feasibility and desirability of extending international human rights obligations beyond state borders that addresses, among other questions, the precise requirements of (effective) state power and control, the distinction between jurisdiction and state responsibility, the role of attribution in

51. For an overview of the relevant Treaty Body commentary, see generally Olivier De Schutter et al., Commentary to the Maastricht Principles on Extraterritorial Obligations of States in the Area of Economic, Social and Cultural Rights, 34 HUM. RTs, Q. 1084 (2012).

52. In its advisory opinion on the legality of the wall in occupied Palestinian territory, for example, the International Court of Justice endorsed the view of the Committee on Economic, Social and Cultural Rights that "the state party's obligations under the Covenant apply to all territories and populations under its effective control." See Legal Consequences of the Construction of a Wall in the Occupied Palestinian Territory, Advisory Opinion, 2004 I.C.J. 131, 112 (July 9). On this basis, the Court held that the construction of the wall impeded, inter alia, "the exercise by the persons concerned of the right to work, to health, to education and to an adequate standard of living as proclaimed in the International Covenant on Economic, Social and Cultural Rights and in the United Nations Convention on the Rights of the Child." Id. I 134 (referencing ESCOR, Concluding Observations of the Committee on Economic, Social and Cultural Rights: Israel, ๆף 15, 31, U.N. Doc. E/C.12/1/Add.90 (May 23, 2003)).

53. See Al-Skeini App. No. 55721/07, 53 Eur. Ct. H.R. I 133; Saldaño v. Argentina, Petitions and Cases Declared Inadmissible, Inter-Am. Comm'n H.R., Report No. 38/99, OEA/Ser.L/V/II.95, doc. 7 rev. I 17 (1999).

54. ESCOR, Comm. on Econ., Soc. \& Cultural Rts, General Comment 19, The Right to Social Security, I 54, Rep. on its 39th Sess., Nov. 5-23, 2007, U.N. Doc. E/C.12/GC/19 (Feb. $4,2008)$.

55. ETO CONSORTIUM, MAastricht PRINCIPLES ON THE EXTRATERritorial Obligations of States in the AREa of Economic, Social and Cultural Rights 6 (2013), quoted in De Schutter et al., supra note 51, at 1101. 
relation to both, and the problem of causation. ${ }^{56}$ While these debates are undoubtedly important in spelling out more concretely the conditions for an extraterritorial application of international human rights treaties, they should not distract from the underlying normative concerns. Doctrinal arguments about the conditions under which a state can be held legally accountable for extraterritorial human rights violations reflect normative judgments about the appropriate role of human rights in construing an agency relationship between that state and an individual located outside its borders. Human rights jurisdiction thus circumscribes a rights-based "relationship between the individual and the State in relation to [violations of human rights] wherever they occurred." 57 In Part III, I argued that, by empowering individuals to partake in the definition of the public good, human rights enable them to consider state power not merely as a factual constraint on their freedom but also as the legitimate expression of collective political willformation. On the one hand, disentangling human rights jurisdiction from state territory yields an extension of rights-based entitlements to all individuals under the state's power and control, wherever located. This ensures legal accountability for the global human rights impacts of state-based decisions concerning the production, distribution, and alignment of public goods. On the other hand, however, it severs the internal relationship between human rights protection and democratic self-legislation traditionally vested in the territorial state legal order. In place of this relationship, disentangling human rights jurisdiction and state territory confronts the state polity with the human rights claims of individuals outside its borders who are concerned by, and therefore have a legitimate say in, the political definition of the state's public good as a representation of the general interest that all of its members hold in common. Seen in this light, similarly to the global-public-goods approach, extending human rights jurisdiction beyond state territory does not give rise to a global conception of political authority that could render decisions about public goods legitimate in the light of a global

56. See, e.g., GLobal JUSTICE, State Duties: The Extraterritorial Scope of ECONOMIC, SOCIAL, AND CULTURAL RIGHTS IN INTERNATIONAL LAW (Malcolm Langford et al. eds., 2012); MARCo MILANOVIC, EXTRATERRITORIAL APPIICATION OF HUMAN RIGHTS Treaties: LAW, Principles, AND Policy (2011); MichaE GONDEK, THE REACH OF HUMAN Rights IN a GLOBalizing WORLD: EXTRATERRITORIAL APPLICATION OF HuMAN RightS Treaties (2009); Sigrun Skogly, Beyond National Borders: STATES' HuMan Rights OBLIGATIONS IN INTERNATIONAL COOPERATION (2006); EXTRATERRITORIAL APPLICATION OF Human Rights Treaties (Fons Coomans \& Menno T. Kamminga eds., 2004).

57. Hum. Rts. Council, Rep. on its 13th Sess., July 29, 1981, Comm. No. 52/1979 (Saldias de Lopez v. Uru.), U.N. Doc. CCPR/C/OP/1 at 88 I 12.2 (July 1984) (emphasis added). 
public good. It merely decenters the constitutive role of human rights in the definition of the public good from the nation-state, in order to contribute to the transformation of the facticity of state power into legitimate legal authority beyond state borders.

\section{Conclusion: Public Goods, Human Rights, AND THE TRANSFORMATION OF STATEHOOD}

Attempts to account for global public goods are marked by a tension between economic concerns with their efficient production, distribution, and alignment in and for a global market, and the localization of political and legal authority in the international order of states. At the same time, global interdependencies in the production and consumption of public goods challenge the nation-state as a blueprint for a territorially-confined political community in which collective-action problems are resolved in the light of the public good. This challenge, so I have argued, cannot be satisfactorily addressed by positing interests and values of common global concern-be it in terms of global costs and benefits associated with public goods, or in terms of universal membership in the human family of rights-bearing subjects. Rather, it requires us to revisit our state-centered assumptions about the nature and operation of law and politics under conditions of globalization. In this vein, scholars of political cosmopolitanism and global constitutionalism have advanced arguments in favor of a further "vertical" integration of the international order of states that accounts for the cross-functional and transboundary impacts of public goods on human wealth and well-being.

Political cosmopolitans envisage the creation of a democratic world system that, for many, should take the form of a suitably reformed United Nations. David Held, for example, imagines a "global assembly" that brings together all states and agencies to authoritatively rule over a world citizenry endowed with equal rights and duties: this "posits the idea of a global political order in which people can enjoy an equality of status with respect to the fundamental processes and institutions which govern their life expectancy and life chances." 58 In a similar vein, Jürgen Habermas sees a world once dominated by nation-states in transition toward a "postnational constellation of a global society" that governs itself through a "global domestic politics without world

58. Held, supra note 15 , at 386. 
government ... embedded within the framework of a world organization with the power to impose peace and implement human rights." 59

If political cosmopolitanism aims at enhancing the global democratic legitimacy of public goods, scholars of global constitutionalism call for a further integration of international law to ensure legal accountability for their global human rights impacts. Here, the functional differentiation of global politics finds its counterpart in an increasing fragmentation of international law. If "increased globalization generates pressures for greater numbers of international rules in more areas of international life," the "greater density of international norms in greater numbers of functionally separate international regimes heightens the dangers associated with the fragmentation of international law."60 Moreover, the transboundary impacts of global public goods require a more robust account of international law's procedural and substantive legitimacy that compensates for the global shortcomings, and redresses the methodological nationalism, of constitutionalism's state-centered heritage. ${ }^{61}$ In this vein, global constitutionalism views national constitutional law and international public law as bound together by a set of common constitutional principles that govern the globe in matters of general public concern. Within this broader framework, the global constitutionalization of human rights subjects international politics to a public-reason constraint that requires states to take the legitimate concerns of "outsiders" into account. ${ }^{62}$

What I have dubbed the "vertical" integration of the international order of states remains parasitic on a notion of statehood as a political collective individuated in the territorial state legal order-whether, as with political cosmopolitanism, its form is integrated into a democratic world political system or, as with global constitutionalism, its substance is adjusted in light of a set of global constitutional principles. By contrast, the approaches discussed in this contribution-the extension of political jurisdiction over decisions concerning global public goods and the extension of legal jurisdiction over their global human rights impacts-point toward a "horizontal" transformation of statehood across

59. JÜRGEN HABERMAS, Does the Constitutionalization of International Law Still Have a Chance? in THE DIVIDED WEST 115, 136 (2006).

60. Jeffrey L. Dunoff \& Joel P. Trachtman, A Functional Approach to International Constitutionalization, in RULING THE WORLD?: CONSTITUTIONALISM, INTERNATIONAL LAW, AND GLOBal Governance 3, 9 (Jeffrey L. Dunoff \& Joel P. Trachtman eds., 2009).

61. See Anne Peters, Compensatory Constitutionalism: The Function and Potential of Fundamental International Norms and Structures, 19 LEIDEN J. INT'L L. 579, 580 (2006).

62. See generally Mattias Kumm, The Cosmopolitan Turn in Constitutionalism: On the Relationship Between Constitutionalism in and Beyond the State, in RULING THE WORLD? CONSTITUTIONALISM, INTERNATIONAL LAW, AND Global GovernanCE, supra note 60, at 258. 
national-territorial borders that transcends the state-based distinctions between domestic and foreign politics and between constitutional and international law. Both approaches come with problems of their own. The extension of political jurisdiction over public goods to encompass all those "affected" by their costs and benefits comes at the price of their global functional differentiation geared toward the realization of particular interests. The extension of human rights jurisdiction beyond state territory, in turn, severs the internal relationship between human rights and democratic self-legislation in accounting for the general interest of the state polity. Yet, taken together, they may be seen as an incremental attempt to recover the public good beyond the international order of states. To the extent that global interdependencies in the production and consumption of public goods have blurred the statebased distinction between domestic and foreign politics, the globalpublic-goods approach provides presumptive justifications for state intervention to prevent "market failures" in matters of common global concern. To be legitimate, such global assertions of state power must be accompanied by the recognition of the rights-based claims of those affected by, and to therefore have a legitimate say in, the definition of the state's public good. This, finally, entails a political reading of the "all affected" principle that settles conflicts about global public goods in light of normative judgments about the appropriate role of human rights in mediating the tension between state power and legitimate legal authority beyond the state-based constitutional/international law divide. 